\title{
Karyotype of the Hawksbill Turtle, Eretmochelys imbricata, from Japan, with Notes on a Method for Preparation of Chromosomes from Liver Cells
}

\author{
NAOKI KAMEZAKI
}

\begin{abstract}
The karyotype of the hawksbill turtle, Eretmochelys imbricata, from Japan was obtained from liver cells. This species has $2 n=56$ homologous chromosomes forming a graded series. Comparison of the present karyotype with those of other cheloniids confirms the strong chromosomal conservativeness within the family. Methodological novelities of the present study are also discussed.
\end{abstract}

Key words: Cheloniidae; Eretmochelys imbricata; Karyotype; Liver cell

Karyotypes of the suborder Cryptodira show little variation, and all or most of the species of a single family appear identical with each other karyotypically (Bickham and Carr, 1983; Bickham, 1983). In the family Cheloniidae, karyotypes of three species, Chelonia mydas, Lepidochelys olivacea and Caretta caretta have been described (Bickham et al., 1980; Bhunya and Mohanty-Hejimadi, 1986; Kamezaki, 1989). These studies revealed that there are no recognizable differences among the standard karyotypes of the three species. On the other hand, Bickham (1981) and Bickham and Carr (1983) noted that the hawksbill turtle, Eretmochelys imbricata, without locality data, had 56 chromosomes, but without providing detailed description of the karyotype.

In this study, I investigated the karyotype of the hawksbill turtle from the Yaeyama Islands, Ryukyu Archipelago, using metaphase liver cells. The results further confirmed the assumption of low chromosomal variability within the family Cheloniidae.

\section{Materials and Methods}

Two female hatchlings were used. These hatched on a beach of Kuroshima Island $\left(124^{\circ} \mathrm{E}\right.$, $24^{\circ} \mathrm{N}$ ) of the Yaeyama Islands, Ryukyu Archipelago, in 1988.

The hatchlings were injected with $0.02 \mathrm{ml}$ of colchicine solution $(1 \mathrm{mg} / \mathrm{ml})$ and $0.01 \mathrm{ml}$ of Phytohemagglutinin M (PHA; Difco) solution per $10 \mathrm{~g}$ of body weight. The injection of PHA followed Lin (1982). Twenty hours after the injection, the liver tissue was taken out and minced with scissors. The cell suspension was made by stirring the minced tissue in $0.1 \%$ tripsine $(+0.02 \%$ EDTA $)$ in a balanced salt solution for

Accepted 11 July 1990 ca. $25 \mathrm{~min}$. The cells were treated with $0.07 \mathrm{M}$ hypotonic $\mathrm{KCl}$ solution for $40 \mathrm{~min}$, followed by fixation in Carnoy's solution. The fixative was changed three times at ten minute intervals. Metaphase chromosome spreads were obtained by an air-dry method and stained with $2 \%$ Giemsa solution in Sörensen phosphate buffer at $\mathrm{pH}$ 5.8. The karyotype was determined on the basis of 14 well-spread cells. Each specimen was sexed by microscopic investigation of gonadal sections.

\section{Results and Discussion}

The karyotype consists of $2 \mathrm{n}=56$ chromosomes. Of these, pairs $2,6,8,9$, and 10 were regarded as metacentric, pair 1 submetacentric, pair 3 subterocentric, and pairs $4,5,7$, and 11 acrocentric elements. The rest were classified as micro-chromosomes (Fig. 1).

The diploid number of the present sample agrees with that reported by Bickham (1981) and Bickham and Carr (1983) for this species. Chromosome morphology of E. imbricata agrees with those of $C$. mydas, L. olivacea and C. caretta at least in a standard Giemsa stained karyotype (Bickham et al., 1980; Bhunya and Mohanty-Hejimadi, 1986; Kamezaki, 1989).

The close resemblance among karyotypes of these species is in favor of the assumption that the karyotype is very conservative within the family Cheloniidae (Bickham, 1981). Karyological investigations of the remaining two cheloniid species, L. kempi and Natator depressa, and further detailed analyses of chelonian karyotypes with banding techniques are required to draw a conclusion upon the variability of the karyotype in this family.

The method of obtaining isolated cells from the liver tissue was designed for the investigation on chromosomes of mice (e.g., Tanaka and 


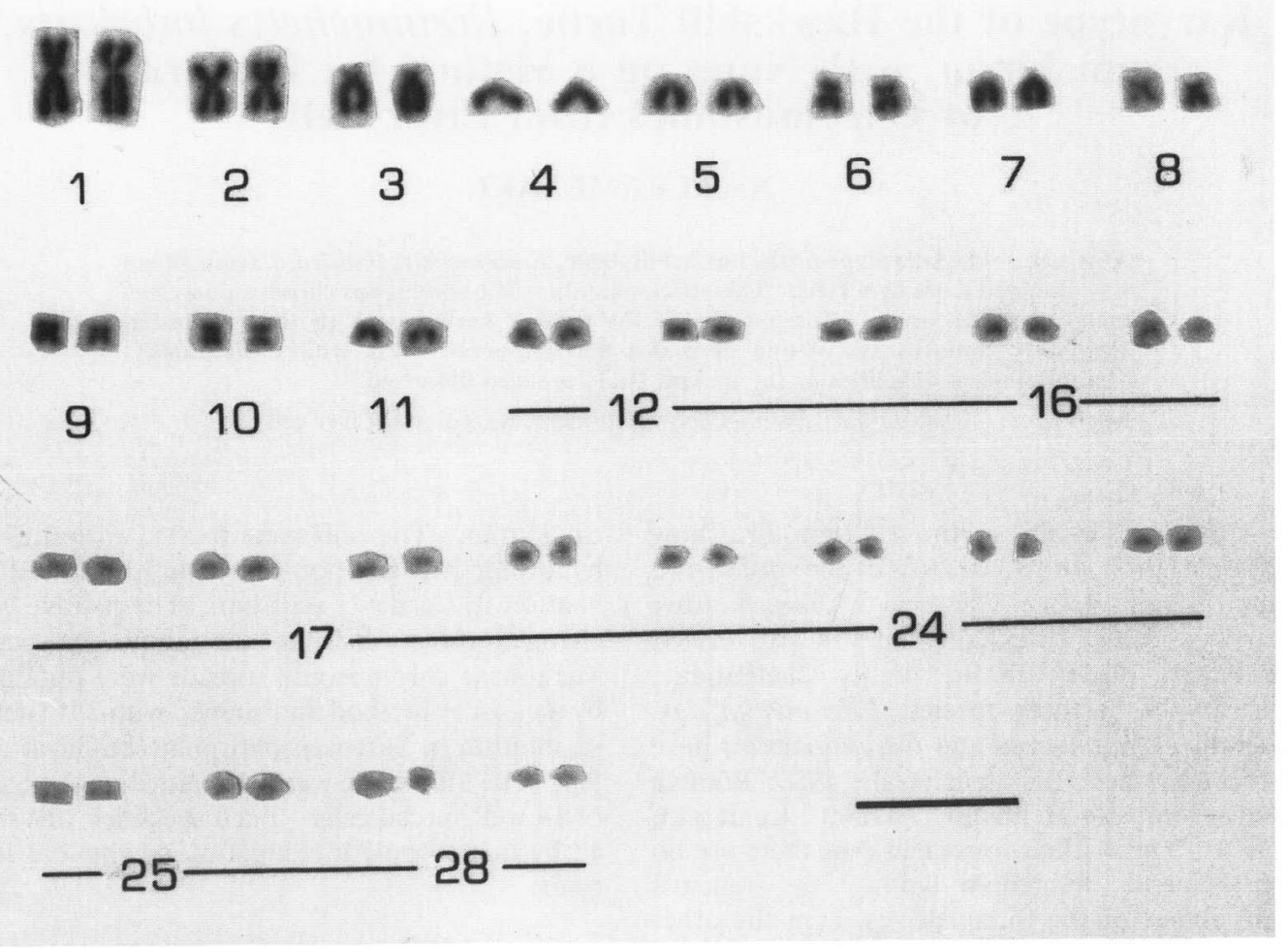

Fig. 1. Karyotype of a female Eretmochelys imbricata from the Ryukyu Archipelago, Japan. The scale indicates $10 \mu \mathrm{m}$.

Ichihara, 1978), and this is the first application of this technique to the karyological study of Testudines. It has been pointed out that the karyotype of mouse liver cells varies in ploidy level (Epstein, 1967; Tulp et al., 1976). However, no such variation was recognized among the cells from $E$. imbricata examined in the present study. This seems to indicate the probable utility of this method for the karyological survey of turtles.

ACKnowledgments.-I thank K. Hirate and F. Iwase of Yaeyama Marine Park Research Station for providing samples, M. Tasumi for facilities, and $\mathrm{T}$. Hikida and $\mathrm{H}$. Ota for reviewing the manuscript. I express my special thanks to $\mathrm{K}$. Yamamoto and $\mathrm{H}$. Nakamura for their technical advice.

\section{Literature Cited}

BiCKнAM, J. W. 1981. Two hundred million year old chromosomes: Deceleration of the rate of karyotypic evolution in turtles. Science 212(2): 1291-1293.

Bickнам, J. W. 1983. Patterns and modes of chromosomal evolution in reptiles. In: A. K. Shar- ma and A. Sharma (eds.), Chromosomes in Evolution of Eukaryotic Groups. Vol. 2. p. 13-40. CRC Press, Florida.

Bickham, J. W., K. A. BJoRndal, M. W. HaiduK AND W. E. RAINEY. 1980. The karyotype and chromosomal banding patterns of the green turtle (Chelonia mydas). Copeia 1980(3): 540-543.

Bickham, J. W. AND J. L. CARR. 1983. Taxonomy and phylogeny of the higher categories of Cryptodiran turtles based on a cladistic analysis of chromosomal data. Copeia 1983(4): 918-932.

Bhunya, S. P. and P. Mohanty-Hejimadi. 1986. Somatic chromosome study of a sea turtle, Lepidochelys olivacea (Chelonia, Reptillia). Chrom. Inf. Serv. 40: 12-14.

Epstein, C. J. 1967. Cell size, nuclear content and development of polyploidy in the mammalian liver. Proc. Natl. Acad. Sci. USA 57(2): 327-334.

KAMEZAKI, N. 1989. Karyotype of the loggerhead turtle, Caretta caretta, from Japan. Zool. Sci. 6(2): 421-422.

LIN, Y. 1982. A PHA injection method in vivo for the rapid obtainment of large numbers of metaphase figures from kidney cell of teleosts. J. Fish. China 6: 201-208.

TANAKA, K. AND A. IChIHARA. 1978. Isolation and 
primary culture of adult rat. Tanpakushitsu Kakusan Kōso (Protein, Nucleic Acid and Enzyme) 23(13): 1259-1271. (in Japanese)

Tulp, A., J. J. M. N. Welagen and P. Emmelot. 1976. Separation of intact rat hepatocytes and rat liver nuclei into ploidy classes by velocity sedimenta-

要 旨 肝細胞をもちいたタイマイの核型分析

亀崎 直樹

八重山諸島で捊化したタイマイ Eretmochelys imbricata の幼体の肝細胞をもちいて，本種の 核型を観察した。その結果，染色体数は $2 \mathrm{n}=56$ で,これまで報告されだミガメ科 3 tion at unit gravity. Biochem. Biophys. Acta 451(2): 567-582.

Department of Zoology, Faculty of Science, Kyoto University, Kitashirakawa-Oiwakecho, Sakyo-ku, Kyoto, 606 JAPAN

種の核型と類似して扣り,この科内に拈ける核 型の分化の低さを改めて確認した。また, 肝細 胞から分裂像を得る方法について述べた。

(606 京都市左京区北白川追分町 京都大学理 学部動物学教室) 